\title{
Meningkatkan Hasil Belajar PKn Materi Kebebasan Berorganisasi Melalui Metode Card Sort pada Siswa Kelas V SDN 5 Sengkol Tahun Pelajaran 2018/2019
}

\author{
H. Agus Argawan Budi \\ Kepala SDN 5 Sengkol Lombok Tengah
}

\begin{abstract}
Abstrak; Penelitian ini dilatarbelakangi adanya kenyataan bahwa masih rendahnya hasil belajar mata pelajaran PKn pada siswa kelas V SDN 5 Sengkol. Oleh karena itu guru di harapkan untuk mencoba suatu metode yang efektif dan menyenangkan dalam meningkatkan prestasi belajar siswa. Metode pembelajaran yang memungkinkan dapat berpengaruh terhadap Hasil belajar siswa adalah metode Card Sort. Penelitian ini bertujuan untuk mengetahui hasil yang di peroleh peserta didik setelah di terapkannya metode Card Sort serta faham pembelajaran PKn pada siswa kelas V SDN 5 Sengkol. Masalah utama yang ingin di jawab dalam penelitian ini adalah apakah dengan menggunakan metode Card Sort dapat meningkatkan hasil belajar PKn pada siswa kelas V SDN 5 Sengkol?. Jenis penelitian yang digunakan adalah Penelitian Tindakan Kelas dengan menggunakan metode Card Sort. Subjek penelitian adalah siswa kelas V SDN 5 Sengkol tahun pelajaran 2018/2019 dengan jumlah siswa 21 orang terdiri atas 8 laki dan 13 perempuan. Data penelitian ini di ambil melalui pemberian tes formatif untuk mengetahui hasil belajar siswa, dengan materi pokok memahami kebebasan berorganisasi. Melihat hasil belajar siswa terus menunjukkan hasil yang signifikan pada siklus I nilai rata - rata yang diperoleh sebesar 66,71 meningkat pada siklus II sebesar 85,19 meningkat sebesar 18,48 poin, jumlah siswa yang tuntas pada siklus I sebnayak 8 orang dengan persentase sebesar 38\% kemudian meningkat pada siklus II jumlah siswa yang tuntas sebanyak 20 orang dengan persentase sebesar $95 \%$ terjadi peningkatan sebesar 57 poin. Ketuntasan klasikal yang dipersyaratkan sebesar $\geq 80 \%$ sudah tercapai. Dengan demikian maka dapat disimpulkan bahwa metode Card Sort dapat meningkatkan hasil belajar siswa kelas V pada mata pelajaran PKn di SDN 5 Sengkol tahun pelajaran 2018/ 2019.
\end{abstract}

\section{Kata kunci : Hasil belajar, metode Card Sort,}

\section{PENDAHULUAN}

Pendidikan Kewarganegaraan

(PKn) merupakan salah satu mata pelajaran yang dapat meningkatkan kualitas Sumber Daya Manusia (SDM), karena dalam mata pelajaran PKn terdapat materi tentang nilai moral yang penting untuk kemajuan SDM. PKn sendiri adalah mata pelajaran yang di gunakan sebagai wahana untuk mengembangkan dan melestarikan nilai luhur dan moral yang berakar pada budaya bangsa Indonesia. Nilai luhur dan moral ini di harapkan dapat di wujutkan dalam bentuk perilaku kehidupan siswa sehari-hari, baik sebagai individu maupun anggota masyarakat, dan makhluk ciptaan Tuhan Yang Maha Esa, yang merupakan usaha untuk membekali siswa dengan pengetahuan dan kemampuan Jurnal Pendidikan Mandala dasar berkenaan dengan hubungan antar warga dengan negara serta pendidikan pendahuluan bela negara agar menjadi warga negara yang dapat diandalkan oleh bangsa dan negara (Ahmad Susanto, $2013: 225$ ).

Berdasarkan hasil ulangan harian yang dilakukan di kelas V SDN 5 Sengkol, ditemukan bahwa kemampuan siswa dalam menguasai mata pelajaran PKn tergolong rendah. Hal ini dapat dilihat dari kriteria ketuntasan mengajar yang di terapakan untuk mata pelajaran PKn adalah 75. Dari hasil ulangan diketahui bahwa dari sejumlah 21 siswa, 8 siswa memperoleh nilai sesuai KKM dan 13 siswa yang lain belum memenuhi KKM yang ditentukan.

Penyebab rendahnya kemampuan 
dalam pembelajaran PKn adalah faktor dari siswa sendiri dan faktor guru kelas. Faktor penyebab dari siswa adalah siswa cenderung kurang dapat mempertahankan daya ingatnya dalam jangka panjang. Sedangkan faktor penyebab rendahnya kemampuan siswa dari faktor guru kelas adalah kurangnya kreativitas guru dalam menggunakan metode pembelajaran yang efektif dan efisien. Masih banyak guru yang menggunakan metode konvensional secara monoton dalam kegiatan pembelajaran di kelas, sehingga suasana belajar terkesan kaku dan di dominasi oleh seorang guru. Metode yang monoton itu contohnya seperti metode ceramah. Metode ceramah adalah cara menyajikan pelajaran melalui penuturan secara lisan atau penjelasan langsung kepada kelompok siswa (Sanjaya, 2006 : 147). Dari penjelasan di atas dapat di simpulkan bahwa metode ceramah merupkan metode yang menjadikan siswa cenderung pasif karena siswa hanya mendengarkan penjelasan dari guru. Hal ini berdampak pada rendahnya hasil belajar siswa khususnya pada materi memahami kebebasan berorganisasi. Dampak ini dapat diatasi dengan pemilihan metode yang tepat dan sesuai dengan materi yang akan di sampaikan.

Menurut penulis metode yang tepat untuk mata pelajaran PKn khususnya materi memahami kebebasan berorganisasi adalah dengan metode Card Sort. Metode Card Sort adalah suatu kegiatan kolaboratif yang bisa di gunakan untuk mengajar konsep, karakteristik klasifikasi, fakta tentang obyek atau mereview informasi. Gerakan fisik yang dominan dalam strategi ini dapat membantu mendinamisir kelas yang jenuh atau bosan (Hisyam,2002 : 50). Dengan metode tersebut siswa dituntut untuk lebih aktif, berfikir cepat dan tepat.

Berdasarkan uraian di atas, penulis tertarik untuk menyusun penelitian tindakan kelas dengan judul " Meningkatkan Hasil Belajar PKn Materi Memahami Kebebasan Berorganisasi melalui Metode Card Sort pada Siswa Kelas V SDN 5 Sengkol Tahun Pelajaran 2018/2019.

Jurnal Pendidikan Mandala

\section{LANDASAN TEORI \\ Pengertian hasil belajar}

Menurut kamus besar bahasa Indonesia (Siti Nurjanah, 2007: 14), hasil belajar adalah penguasaan pengetahuan atau keterampilan yang dikembangkan oleh mata pelajaran, lazimnya ditunjukkan dengan nilai tes atau nilai yang diberikan kepuasan kepada individu yang belajar. Nana Sudjana (2002: 22) menyatakan bahwa hasil belajar merupakan kemampuan-kemampuan yang dimiliki setelah seseorang memiliki pengalaman belajarnya. Jadi dapat disimpulkan bahwa hasil belajar adalah kemampuan-kemampuan yang diperoleh siswa melalui kegiatan belajar. Siswa yang berhasil dalam belajar yaitu yang berhasil mencapai tujuan-tujuan pembelajaran.

Hasil belajar ditentukan oleh evaluasi. Evaluasi hasil belajar merupakan proses untuk menentukan nilai belajar siswa melalui kegiatan penilaian dan pengukuran hasil belajar. Tujuan utama evaluasi adalah untuk mengetahui tingkat keberhasilan yang dicapai siswa setelah mengikuti suatu kegiatan pembelajaran. Tingkat keberhasilan dapat dinyatakan dalam huruf, kata atau simbol (Dimyati Mudjiono, 2002: 200).

Faktor-faktor yang mempengaruhi hasil belajar

Belajar merupakan proses menimbulkan terjadinya perubahan atau pembaharuan dalam tingkahlaku. Jadi berhasil tidaknya seseorang dalam proses belajar tergantung dari faktor-faktor yang mempengaruhinya. Menurut Muhibbin Syah (2010 :145-157) dalam bukunya Psikologi Belajar mengemukakan bahwa faktor-faktor yang mempengaruhi belajar siswa dapat di bedakan menajadi tiga macam, yaitu faktor internal, faktor eksternal dan faktor pendekatan belajar.

\section{Faktor internal siswa}

Faktor yang berasal dari dalam diri siswa sendiri meliputi dua aspek yaitu : aspek fisiologis (yang bersifat jasmaniah) dan aspek psikologis (yang bersifat rohaniah).

1) Aspek fisiologis (faktor jasmaniah) 
Kondisi umum jasmaniah dan tonus (tegangan otot) yang menandai tingkat kebugaran organorgan tubuh dan sendi- sendinya, dapat mempengaruhi semangat dan intensitas siswa dalam mengikuti pelajaran. Kondisi organorgan khusus siswa, seprti tingkat kesehatan indera pendengaran dan indera penglihatan, juga sangat mempengaruhi kemampuan siswa dalam menyerap informasi dan pengetahuan, khususnya yang di sajikan di kelas.

\section{2) Faktor psikologis}

Faktor-faktor rohaniah siswa yang pada umumnya di pandang lebih esensial itu adalah sebagai berikut : 1) tingkat kecerdasan/ intelegensi siswa, 2) sikap siswa, 3) bakat siswa, 4) minat siswa, 5) motivasi siswa.

\section{b. Faktor eksternal siswa}

Seperti faktor internal siswa, faktor eksternal siswa juga terdiri atas dua macam, yakni : faktor lingkungan sosial dan faktor lingkungan non sosial.

1) Lingkungan sosial

Lingkungan sosial sekolah seperti; orang tua, keluarga,mmayarakata, tetangga, teman sepermainan, para guru, para staf administrasi, dan teman-teman sekelasnya dapat mempengaruhi semangat belajar seorang siswa. Para guru yang selalu menunjukkan sikap dan perilaku yang simpatik dan memperlihatkan suri teladan yang baik dan rajin khususnya dalam hal belajar, misalnya rajin membaca dan berdiskusi, dapat menajadikan daya dorong yang positif bagi kegiatan belajar siswa.

Lingkungan sosial yang lebih banyak mempengaruhi kegiatan belajar ialah orang tua dan keluarga siswa itu sendiri. Sifat-sifat orang tua, praktik pengelolaan keluarga, ketegangan keluarga, dan demografi keluarga (letak rumah), semuanya dapat memberi dampak baik ataupun buruk terhadap kegiatan belajar dan hasil yang di capai oleh siswa.

2) Lingkungan nonsosial

Faktor-faktor yang termasuk lingkungan nonsosial ialah gedung sekolah dan letaknya, rumah tempat tinggal keluarga siswa dan letaknya, alat-alat belajar, keadaan Jurnal Pendidikan Mandala cuaca dan waktu belajar yang di gunakan siswa. Faktor-faktor ini di pandang turut tingkat keberhasilan belajar siswa.

Rumah yang sempit dan berantakan serta perkampungan yang terlalu padat dan tak memiliki sarana umum untuk kegiatan remaja akan mandorong siswa untuk berkeliaran ke tempat- tempat yang sebenarnya tak pantas di kunjungi. Kondisi rumah dan pekampungan seperti itu jelas berpengaruh buruk terhadap kegiatan belajar siswa.

\section{c. Faktor pendekatan belajar}

Pendekatan belajar dapat di pahami sebagai segala cara atau strategi yang di gunakan siswa dalam manunjang keefektifan dan efesiensi proses pembelajaran materi tertentu. Faktor pendekatan belajar juga berpengaruh terhadap taraf keberhasilan proses belajar siswa tersebut.

2. Prinsip-prinsip belajar

Menurut Slameto (1991 : 29)

prinsip-prinsip belajar ada beberapa macam yaitu sebagai berikut ; (a,) dalam belajar setiap siswa harus di usahakan partisipasi aktif, meningkatkan minat dan membimbing untuk mencapai tujuan instruksional,(b) belajar bersifat keseluruhan dan materi itu harus memiliki struktur, penyajian yang sederhana, sehingga siswa mudah menangkap pengertiannya, (c) belajar harus dapat menimbulkan reinforcement dan motivasi yang kuat pada siswa untuk mencapai tujuan instruksional,(d) belajar itu proses kontinyu, maka harus tahap demi tahap menurut perkembangannya, (e) belajar adalah proses organisasi, adaptasi, eksplorasi dan discovery, ( f) belajar harus dapat mengembangkan kemampuan tertentu sesuai dengan tujuan instruksional yang harus di capainya, (g) gelajar memerlukan sarana yang cukup sehingga siswa dapat belajar dengan tenang (h) belajar perlu lingkungan yang menantang dimana anak dapat ( i) mengembangkan kemampuannya bereksplorasi dan belajar dengan efektif, (elajar perlu ada interaksi siswa dengan lingkungannya. 


\section{Karakteristik pelajaran Pendidikan Kewarganegaraan}

PKn adalah nama dari suatu mata pelajaran yang terdapat dalam kurikulum sekolah. PKn berusaha membina perkembangan moral anak didik sesuai dengan nilai-nilai Pancasila, agar dapat mencapai perkembangan secara optimal dan dapat mewujudkan dalam kehidupan seharihari (Daryono, 1998 : 1). Sedangkan menurut Ahmad Susanto (2013 : 225) Pendidikan Kewarganegaraan adalah mata pelajaran yang di gunakan sebagai wahana untuk mengembangkan dan melestarikan nilai luhur dan moral yang berakar pada budaya bangsa Indonesia.

Berdasarkan definisi- definisi di atas dapat di ambil kesimpulan bahwa Pendidikan Kewarganegaraan adalah pendidikan untuk mengarahkan pembentukan moral yang di wujudkan dalam perilaku sehari-hari dan membekali pengetahuan serta kemampuan dasar berkenaan dengan hubungan antar warga negara dengan negara serta pendahuluan bela negara. Melalui Pendidikan Kewarganegaraan ini para siswa di harapkan mampu mengembangkan potensinya baik sebagai pribadi, anggota masyarakat, bangsa dan negara, namun sebagai anggota masyarakat dunia.

\section{Latar Belakang PKn}

Pendidikan secara formal

dilakukan oleh suatu lembaga yang disebut dengan sekolah. Dalam proses pendidikan di sekolah melibatkan banyak komponen diantaranya guru, siswa, bahan ajar, sarana dan prasarana, sumber belajar, media pembelajaran, dan sebagainya. Masingmasing faktor yang terlibat dalam proses pembelajaran itu mempunyai fungsi yang berbeda satu dengan yang lain, akan tetapi saling berhubungan dan saling mendukung.

Menurut Pasal 3 Undang-Undang

Sistem Pendidikan Nasional (Sisdiknas) Tahun 2003, tujuan Pendidikan Nasional adalah mengembangkan potensi peserta didik menjadi manusia yang beriman dan bertaqwa kepada Tuhan Yang Maha Esa, berakhlak Jurnal Pendidikan Mandala mulia, sehat, berilmu, cakap, kreatif, mandiri, dan menjadi warga negara yang demokratis serta bertanggungjawab. Melalui pendidikan nasional diharapkan dapat ditingkatkan kemampuan, mutu kehidupan, dan martabat manusia Indonesia. Untuk itu, pendidikan nasional diharapkan menghasilkan manusia terdidik yang beriman, berbudi pekerti luhur, berpengetahuan, berketerampilan, dan memiliki rasa tanggungjawab.

Mata pelajaran Pendidikan Kewarganegaraan (PKn) merupakan mata pelajaran yang di dalamnya memuat rumpun hukum, politik dan moral. PKn merupakan salah satu mata pelajaran yang diberikan di jenjang pendidikan Sekolah Dasar (SD). Mata Pelajaran PKn merupakan mata pelajaran yang memfokuskan pada pembentukan warga negara yang memahami dan mampu melaksanakan hak-hak dan kewajibannya untuk menjadi warganegara Indonesia yang cerdas, terampil, dan berkarakter seperti yang diamanatkan oleh Pancasila dan UUD 1945 (Peraturan Menteri Pendidikan Nasional No. 22 Tahun 2006).

Menurut Permendiknas No. 23 Tahun 2006 mata pelajaran PKn di SD bertujuan agar peserta didik memiliki kemampuan sebagai berikut :

- Berpikir secara kritis, rasional, dan kreatif dalam menanggapi isu kewarganegaraan.

- Berpartisipasi secara aktif dan bertanggung jawab, dan bertindak secara cerdas dalam kegiatan bermasyarakat, berbangsa, dan bernegara, serta anti-korupsi.

- Berkembang secara positif dan demokratis untuk membentuk diri berdasarkan karakter-karakter masyarakat Indonesia agar dapat hidup bersama dengan bangsabangsa lainnya.

- Berinteraksi dengan bangsa-bangsa lain dalam percaturan dunia secara langsung atau tidak langsung dengan memanfaatkan teknologi informasi dan komunikasi. Dari tujuan ini kemudian di kembangkan paradigma baru pendidikan kewarganegaraan. Paradigma baru ini tidak hanya menekankan pada aspek 
pengetahuan (knowledge) saja melainkan juga aspek keterampilan (skills) dan nilai (values) berupa watak kewarganegaraan.

Menurut Peraturan Menteri Pendidikan Nasional Nomor 23 Tahun 2006 tanggal 23 mei 2006 kelompok mata pelajaran Kewarganegaraan dan Kepribadian bertujuan untuk membentuk peserta didik menjadi manusia yang memiliki rasa kebangsaan dan cinta tanah air. Tujuan ini dicapai melalui muatan dan/atau kegiatan agama, akhlak mulia, kewarganegaraan, bahasa, seni dan budaya, dan pendidikan jasmani.

$$
\text { Adapun Standar Kompetensi }
$$

Kelompok Mata Pelajaran (SK-KMP) untuk Kewarganegaraan dan Kepribadian SD/MI/SDLB adalah ; a) Menunjukkan kecintaan dan kebanggaan terhadap bangsa, negara, dan tanah air Indonesia,b) Mematuhi aturan-aturan sosial yang berlaku dalam lingkungannya, c) Menghargai keberagaman agama, budaya, suku, ras, dan golongan sosial ekonomi di lingkungan sekitarnya, d) Menunjukkan kecintaan dan kepedulian terhadap lingkungan, e) Mengenal kekurangan dan kelebihan diri sendiri, f) Menunjukkan rasa keingintahuan yang tinggi dan menyadari potensinya (http://ardianzahnur.blogspot.com/2012/08/im plementasi-permendiknas-no-23-tahun 2012 1470.html/).

\section{Materi Kebebasan Berorganisasi Memahami organisasi}

Organisasi adalah perkumpulan dua orang atau lebih yang bekerja sama untuk mencapai tujuan bersama. Sekumpulan orang saja belum dapat disebu organisasi, untuk dapat disebut sebagai organisasi kumpulan orang tersebut harus memiliki tujuan. Suatu organisasi mempunyai tujuan yang sama, serta bekerja sama untuk mencapai tujuan yang diinginkan bersama. Banyak hal yang harus ada di dalam organisasi.

Jadi, dalam setiap organisasi mesti ada tujuan bersama. Dari pengertian tersebut, kita dapat mengetahui ciri-ciri organisasi. Ciri-ciri tersebut harus ada pada sebuah organisasi. Semua ciri-ciri tersebut adalah : a. Kumpulan Jurnal Pendidikan Mandala manusia, b. Tujuan bersama, c. Kerjasama, d. Pengetahuan.

Sekumpulan manusia saja belum dapat di sebut sebuah organisasi. Untuk dapat di sebut sebagai organisasi, sekumpulan manusia haruslah memiliki tujuan bersama. Sebuah organisasi yang memiliki tujuan sendirisendiri bukanlah sebuah organisasi. Perhatikan keadaan sekeliling kalian sewaktu berangkat sekolah. Kalian akan menjumpai serombongan orang sedang menunggu bus. Ada juga serombongan orang sedang berangkat ke tempat kerja masing-masing. Rombongan atau kumpulan manusia itu tidak dapat di anggap sebagai organisasi. Alasannya, setiap orang di dalam rombongan itu mempunyai rombongan sendiri-sendiri.

Sekelompok manusia yang mempunyai tujuan bersama, namun di kerjakan sendiri, belum bisa di sebut organisasi. Untuk dapat dapat di sebut organisasi, tujuan bersama harus di capai bersama. Kerja sama tersebut harus melibatkan semua orang di dalam kelompok tersebut. Jadi, semua orang dalam kelompok tersebut harus bersepakat untuk bekerja sama. Semua orang dalam kelompok tersebut harus berusaha mencapai tujuan bersama. Bila salah satu tidak turut serta mengusahakannya, organisasi menjadi macet.

Organisasi-organisasi yang ada di sekitar kita

1. Organisasi sekolah

Sekolah juga dapat di sebut sebagai organisasi. Di sekolah ada kepala sekolah, wakil kepala sekolah, bendahara, dan lainlain. mereka semua memiliki peran penting dalam sekolah adapun peran warga sekolah atau murid. Selain sebagai sebuah organisasi, sekolah juga terdiri atas organisasi-organisasi lainnya. Organisasi-organisasi sekolah anara lain pramuka, koperasi sekolah, uks, dan sebagainya..

2. Organisasi masyarakat

Salah satu organisasi yang paling banyak jenisnya adalah organisasi kemasyarakatan. Oleh karena itu organisasi kemasyarakatan mudah kita temukan. Contohnya ibu-ibu PKK, organisasi pemuda karang taruna, 
organisasi kesenian dan lain-lain,

3. Organisasi pemerintahan

Organisasi pemerintah lebih rumit di banding organisasi kemasyarakatan. Sebab, selain mengurus pemerintahan, organisasi pemerintahan juga mengurus masalah kemasyarakatan

4. Organisasi politik

Organisasi politik tebentuk untuk meraih tujuan. Tujuan tersebut adalah menempatkan anggotanya di organisasi pemerintahan. Contoh dari organisasi politik adalah partai politik.

5. Organisasi ekonomi

Organisasi ekonomi adalah orgaisasi yang memiliki tujuan untuk memperoleh keuntungan ekonomi.

\section{b. Membentuk organisasi kelas}

Sebagai organisasi, kelas juga harus memiliki ciri-ciri organisasi. Kelas merupakan kumpulan beberapa siswa. Mereka belajar bersama-sama. Itulah tujuan semua anggota kelas. Dalam belajar, mereka juga bekerja sama. Mereka saling membantu dan menolong. Dalam belajar, mereka juga memakai aturan-aturan.

Organisasi ini di pimpin oleh siswa terpilih. Ia di pilih oleh semua anggota kelas.Jabatannya adalah ketua kelas. Ketua kelas sebagai pemimpin anggota kelasnya. Ia di bantu oleh sekretasis dan bendahara. Itulah organisasi, semua anggota saling membantu untuk meringankan tugas.

\section{Metode Pembelajaran}

\section{Pengertian metode pembelajaaran}

Metode adalah cara atau jalan yang harus di lalui untuk mencapai suatu tujuan tertentu (Slameto, 1991 : 84). Metode secara harfiah berarti -carall. Dalam pemakaian yang umum, metode di artikan sebagai suatu cara atau prosedur yang di pakai untuk mencapai tujuan tertentu. Kata -pembelajaran $\|$ berarti segala upaya yang di lakukan oleh pendidik agar terjadi proses belajar pada diri peserta didik. Jadi, metode pembelajaran adalah cara-cara menyajikan materi pelajaran yang di lakukan oleh pendidik agar terjadi proses belajar pada diri Jurnal Pendidikan Mandala peserta didik dalam upaya untuk mencapai tujuan (Sutikno, 2014 : 34). Berdasarkan uraian di atas maka dapat di simpulkan bahawa pemilihan metode berpengaruh pada cara pembelajaran yang melatih siswa dalam mencapai keberhasilan kegiatan pembelajaran. Ketepatan dalam pemilihan metode ini dapat berpengaruh terhadap hasil akademik siswa.

\section{Keefektifan penggunaan metode pembelajaran}

Tidak semua guru memiliki karakter yang sama dalam memilih dan menguasai metode pembelajaran agar dapat menghasilkan keberhasilan kegiatan pembelajaran. Banyak metode yang dapat di gunakan guru dalam menyampaikan materi pelajaran. Namun perlu di ingat bahwa tidak semua metode cocok di gunakan dalam sebuah pelajaran. Ketepatan dalam memilih metode terletak pada ketepatan dalam memilih metode dengan tuntutan pembelajaran. Berdasarkan pengalaman membuktikan bahwa kegagalan pembelajran salahsatunya di sebabkan oleh pemilihan metode yang kurang tepat. Keaktifan dan kreatifitas siswa dapat berkurang di karenakan penentuan metode yang kurang sesuai dengan sifat materi, dan tidak sesuai dengan tujuan pembelajaran. Metode pembelajaran siswa tidak dapat di pilih dengan asal-asalan, karena berpengaruh besar terhadap hasil belajar siswa, tetapi pemilihan metode ini sebaiknya melalui seleksi yang sesuai dengan perumusan tujuan pembelajaran. Penggunaan metode yang tidak sesuai akan menjadi kendala dalam pencapaian tujuan pembelajaran.

Keefektifan penggunaan metode dapat terjadi bila ada kesesuaian antara metode dengan semua komponen pembelajaran yang telah di programkan dalam satuan pelajaran. Makin tepat metode yang di gunakan oleh guru dalam pembelajaran, di harapkan makin efektif pula pencapaian tujuan pembelajaran.

1. Faktor-faktor yang mempengaruhi pemilihan metode pembelajaran 
Menurut Sobary Sutikno (2014 : 36 - 39) mengatakan bahwa, pemilihan dan penentuan metode di pengaruhi oleh beberapa faktor, yaitu : (a) Tujuan yang hendak di capai, (b) Materi pelajaran,(c) Situasi, (e) Fasilitas, (f) Guru

\section{Metode Card Sort Konsep Metode Card Sort}

Metode Card Sort sebagai salah satu cara yang menyenangkan dan mengaktifkan siswa untuk meninjau ulang materi yang telah di sampaikan sebelumnya. Dalam buku Sobary Sutikno (2014 : 130-131) Metode mensortir kartu ini (Card Sort) di gunakan oleh peserta didik dengan maksud mengajak peserta didik untuk menemukan konsep dan fakta melalui klasifikasi materi yang di bahas dalam pembelajaran. Tujuan dari metode mensortir kartu ini adalah untuk mengungkapkan daya ingat terhadap materi pelajaran yeng telah di pelajari siswa.

\section{Karakter Metode Card Sort}

Salah satu karakter dalam metode Card Sort yaitu pendidik lebih banyak bertindak sebagai fasilitator dan menjelaskan materi yang perlu di bahas atau materi yang belum di mengerti siswa setelah presentasi selesai. Sehingga materi yang telah di pelajari benar-benar di pahami dan di mengerti oleh siswa. Karakter khas dari pembelajaran aktif metode Card Sort ini adalah siswa mencari bahan sendiri atau materi yang sesuai dengan kategori kelompok yang di perolehnya dan siswa mengelompok sesuai dengan kartu indeks yang di perolehnya. Gerakan fisik yang dominan dapat membantu mendinamisir kelas yang kelelahan. Dengan demikian siswa menjadi aktif dan termotivasi dalam proses belajar mengajar.

\section{Langkah-langkah Metode Card Sort}

Adapun langkah-langkah dalam penerapannya sebagai berikut :

1. Bagi kelas ke dalam beberapa kelompok.

2. Bagikan kertas plano yang telah di beri tulisan kata kunci atau informasi tertentu atau kategori tertentu secara acak kepada setiap kelompok. Pada tempat yang terpisah, letakkan kartu warna-warni yang Jurnal Pendidikan Mandala berisi jawaban/informasi yang tepat untuk masing-masing kata kunci. Buatlah kartukartu itu tercapmur aduk.

3. Mintalah setiap kelompok mencari kartu yang cocok dengan kata kunci tersebut. Jelaskan kepada setiap kelompok bahwa kegiatan ini merupakan latihan pencocokan.

4. Setelah mereka menemukan kartu yang cocok, mintalah mereka menempelkan ke lembar kata kunci sehingga menjadi sebuah informasi.

5. Pendidik memberi tanggapan terhadap jawaban peserta didik.

6. Simpulkan.

\section{Kelebihan Metode Card Sort}

Ada beberapa kelebihan metode card shot antara lain ; (a) Mudah dilaksanakan, (b) Dapat diikuti oleh siswa yang jumlahnya banyak, (c) Mudah menyiapkannya, (d) Guru mudah menerangkan dengan baik, (e) Siswa lebih mudah mengerti tentang materi yang diajarkan daripada dengan menggunakan metode ceramah, (f) Siswa lebih antusias dalam pembelajaran, (g) Sosialisasi antara siswa lebih terbangun yakni antara siswa dengan siswa lebih akrab.

\section{Kelemahan Metode Card Sort}

Ada beberapa kelamahan metode card shot diantaranya; (a) Tidak semua mata pelajaran dapat menggunakan metode Card Sort, (b) Banyak menyita waktu karena menyiapkan model pembelajaran terlebih dahulu.

Metode Card Sort dalam pembelajaran Pendidikan Kewarganegaraan

Pembelajaran di sekolah yang melibatkan siswa dengan guru akan melahirkan nilai yang akan terbawa dan tercermin terus dalam kehidupan bermasyarakat. Pembelajaran yang melibatkan siswa secara aktif dalam kelompok secara bergotong royong akan menimbulkan suasana belajar partisipaif dan menjadi lebih hidup. Metode Card Sort dalam mata pelajaran $\mathrm{PKn}$ dapat mendorong timbulnya gagasan yang lebih bermutu dan 
dapat meningkatkan kreativitas siswa.

Jika pelaksanaan prosedur pembelajaran dengan metode Card Sort ini benar, akan memungkinkan untuk dapat mengaktifkan siswa sehingga dapat meningkatkan hasil belajar siswa. Sudah saatnya para pengajar mengevaluasi cara mengajarnya dan menyadari dampaknya terhadap anak didik. Untuk menghasilkan manusia yang bisa berdamai dan bekerja sama dengan sesamanya dalam pembelajaran di sekolah, metode pembelajaran Card Sort perlu lebih sering di gunakan karna suasana yang positif akan memberikan kesempatan kepada siswa untuk mencintai pelajaran
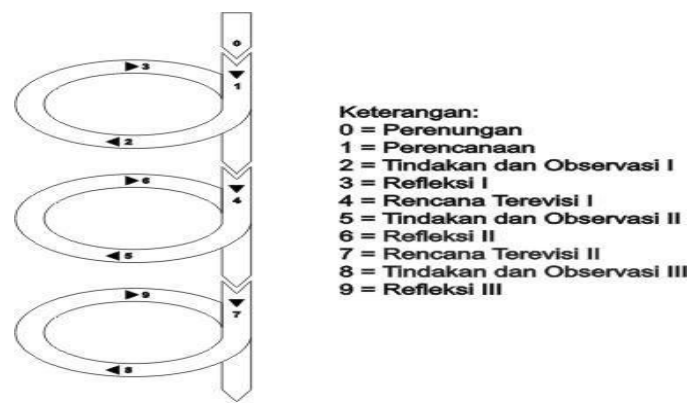

sekolah atau guru. Selain itu, siswa akan merasa lebih terdorong untuk belajar dan berpikir.

\section{METODE PENELITIAN Jenis Penelitian}

Metode yang digunakan dalam penelitian ini adalah penelitian tindakan kelas atau yang sering disebut dengan classroom action research, yaitu suatu pencermatan terhadap kegiatan belajarberupa sebuah tindakan yang disengaja dimunculkan dan terjadi di dalam kelas secara bersama (Suharsimi Arikunto, 2006: 3). Tujuan PTK adalah untuk memperbaiki dan meningkatkan praktek pembelajaran di kelas.

Sedangkan Kemmis dalam menjelaskan bahwa penelitian tindakan kelas adalah sebuah bentuk inkuiri reflektif yang dilakukan secara kemitraan mengenai situasi sosial (termasuk pendidikan) untuk meningkatkan rasionalitas dan keadilan dari: (a) kegiatan praktik social atau Jurnal Pendidikan Mandala pendidikan mereka, (b) pemahaman mereka mengenai kegiatan-kegiatan praktek pendidikan, (c) sesuai yang memungkinkan terlaksananya kegiatan praktek.

Berdasarkan pengertian di atas, penelitian tindakan kelas tersebut, dapat disimpulkan bahwa penelitian tindakan merupakan suatu bentuk penelitian yang bersifat reflektif berupa tindakan-tindakan tertentu agar dapat memperbaiki atau meningkatkan praktek pembelajaran di kelas secara lebih profesional. Penelitian ini berupaya untuk meningkatkan partisipasi dan hasil belajar siswa. Pendekatan yang akan digunakan ini menggunakan pendekatan deskriptif kuantitatif, yang diartikan sebagai prosedur penelitian yang menghasilkan data berupa angka-angka dari partisipasi siswa dan tes hasil belajar siswa.

\section{Desain Penelitian}

Desain penelitian yang dikembangan dalam penelitian ini adalah desain yang diadaptasi dari Kemmis dan Taggart (Suwarsih Madya, 1994: 20), yang menggambarkan bahwa penelitian tindakan kelas dilaksanaan melalui beberapa siklus dan masing-masing terdiri dari 4 tahap. Bagan model spiral Kemmis dan Taggart digambarkan sebagai berikut:

Gambar 5. Proses penelitian tindakan

Secara garis besar, penelitian tindakan kelas model Kemmis \& Taggart terdiri dari empat aspek pokok, yaitu:

\section{Penyusunan Rencana}

Rencana penelitian tindakan merupakan tindakan yang tersusun, dan dari segi prospektif pada tindakan harus memandang ke depan. Perencanaan terdiri atas dua macam yaitu perencanaan umum dan perencanaan khusus. Perencanan umum dimaksudkan untuk menyusun rancangan yang meliputi keseluruhan aspek yang terkait dengan PTK. Perencanaan khusus dimaksudkan untuk menyusun rancangan dari siklus per siklus. Hal yang direncanakan diantaranya terkait dengan pendekatan pembelajaran, media pembelajaran, teknik/strategi pembelajaran, 
materi pembelajaran.

\section{Tindakan}

Tindakan yang dimaksud adalah tindakan yang dilakukan secara sadardan terkendali yang merupakan variasi praktek yang cermat dan bijaksanan. Tindakan bersifat tidak tetap dan dinamis serta memerlukan keputusan cepat tentang apa yang perlu dilakukan dan penelitian praktis.

\section{Observasi}

Observasi berfungsi untuk mendokumentasikan pengaruh tindakan terkait. Observasi berorientasi kemasa yang akan datang, memberikan dasar bagi refleksi sekarang, dan ketikaputaransedang berjalan. Penelitian tindakan perlu mengamati proses tindakannya, pengaruh tindakan, keadaan, dan kendala tindakan.

\section{Refleksi}

Refleksi merupakan wujud kesan atau upaya evaluasi yang dilakukan oleh para partisipasi yang terkait(siswa, guru, dan peneliti) dengan suatu PTK yang dilaksanakan. Refleksi dilakukan secara kolaboratif adanya diskusi terhadap berbagai masalah yang terjadi di kelas penelitian. Refleksi dapat ditentukan adanya implementasi tindakan dan hasil observasi. Berdasarnya refleksi ini suatu perbaikan tindakan (replanning) selanjutnya ditentukan.

\section{Lokasi dan Waktu Penelitian}

Tempat Penelitian

Penelitian ini dilakukan di kelas

V SDN 5 Sengkol yang berlokasi di Desa Sengkol Kecamatan Sengkol kabupaten Lombok Tengah.

Waktu Penelitian

Penelitian tindakan kelas ini dilaksanakan pada semester ganjil tahun pelajaran 2018/2019 bulan September - November 2018, pelaksanaan tindakan disesuaikan dengan jadwal pelajaran PKn kelas V

\section{Subjek Penelitian}

Subjek penelitian ditentukan secara sampling purposive. Menurut Sugiono (2011: 126) sampling purposive Jurnal Pendidikan Mandala adalah teknik penentuan sample dengan pertimbangan tertentu. Subjek dalam penelitian ini adalah siswa kelas V SDN 5 Sengkol, dengan jumlah siswa 21. Sesuai dengan hasil pengamatan dan wawancara secara langsung oleh peneliti sekalligus sebagai Kepala Sekolah di SDN 5 Sengkol menunjukkan bahwa kelas tersebut partisipasi aktif siswa dalam pembelajaran masih rendah, hal ini akan berakibat kurang meningkatnya hasil belajar siswa. Pada kelas tersebut yang nantinya akan dilakukan suatu tindakan kelas. Tindakan tersebut akan dilakukan dengan menerapkan pembelajaran dengan metode card shot.

Teknik Pengumpulan Data

Teknik pengumpulan data dalam penelitian ini adalah sebagai berikut: (1)Observasi, (2) Soal kuis dan tes, (3) Dokumentasi

\section{Instrumen Penelitian}

Menurut Suharsimi Arikunto (2006: 160), instrumen penelitian adalah suatu alat atau fasilitas yang digunakan dalam mengumpulkan data agar lebih mudah dan hasilnya lebih baik dalam arti lebih cermat, lengkap, dan sistematis, sehingga lebih mudah diolah. Untuk mengumpulkan data yang diperlukan dalam penelitian, digunakan beberapa teknik sebagai berikut:

\section{Lembar observasi}

Lembar observasi berisi pedoman dalam melaksanakan pengamatan. Pedoman tersebut digunakan sebagai pedoman dalam mengamati aktivitas belajar siswa selama proses pembelajaran. Aspekaspek yang diamati antara lain: interaksi siswa saat pembelajaran, interaksi siswa dengan guru, interaksi siswa dengan siswa, penggunaan metode card shot, dan keaktifan siswa dalam mengerjakan kuis. Aspek yang diamati dalam penelitian ini adalah aspek yang menunjukan aktivitas pembelajaran metode card shot yang kemudian berdampak pada meningkatnya aktivitas belajar siswa. 
Adapun aspek yang diamati dalam aktivitas pembelajaran metode card shot yaitu mengidentifikasi masalah, menganalisis masalah, menyusun hipotesis, menghimpun dan mengelompokan data, pembuktian hipotesis, menentukan pemecahan masalah, menampilkan penemuan.

\section{Soal Tes}

Tes adalah serentetan untuk mengukur ketrampilan, pengetahuan intelegensi, kemampuan atau bakat yang dimiliki individu. Tes dalam penelitian ini juga menjadikannya sebagai instrumen penelitian. Untuk instrumen tes digunakan pada tes terhadap hasil belajar Pendidikan Kewarganegaraan, yang berbentuk pilihan ganda. Jumlah soal tes sebanyak 20 butir dengan soal pilihan ganda empat alternatif jawaban yaitu a, b, c, dan d. Dalam penyusunan butir instrumen dan kisi-kisi penyusun menggunakan butir soal dengan disesuaikan pada Kurikulum Tingkat Satuan Pendidikan.

\section{Teknik Analisis Data}

Teknik analisis data dalam penelitian ini dengan merefleksikan hasil observasi dari penerapan pembelajaran menggunakan metode card shot dalam meningkatkan keaktifan siswa, dan tes untuk mengetahui prestasi belajar siswa selama poses tindakan berlangsung.

\section{Analisis Data Observasi}

Data proses pembelajaran yang terdapat pada lembar observasi pelaksanaan pembelajaran, dianalisis secara deskriptif untuk tiap siklus. Penilaian dapat dilihat dari hasil skor pada lembar observasi yang digunakan. Data observasi yang telah diperoleh dihitung, kemudian disajikan secara deskriptif.

\section{Analisis hasil belajar siswa}

Teknik analisis data dalam penelitian ini dengan merefleksikan hasil observasi dengan penerapan pembelajaran menggunakan metode card shot untuk peningkatan partisipasi aktif dan tes untuk mengetahui hasil belajar siswa selama proses tindakan berlangsung. Teknik yang Jurnal Pendidikan Mandala digunakan dalam penelitian ini adalah menggunakan teknik statistik deskriptif. Statistik deskriptif merupakan metodemetode yang berkaitan dengan pengumpulan dan penyajian suatu gugus data sehingga memberi informasi yang berguna.

\section{HASIL PENELITIAN}

\section{Hasil Observasi Pada Tahap Pra Siklus}

Sebelum menggunakan metode

Card Sort, penyampaian materi menggunakan metode ceramah tanpa media. Dari dokumentasi sebelum penerapan metode Card Sort didapatkan nilai sebagai pembanding setelah dan sebelum penerapan metode Card Sort sebagai pemecah masalah. Nilai dalam penelitian ini sebagai indikator tingkat pencapaian penggunaan metode Card Sort untuk meningkatkan hasil belajar siswa. Sebagai patokan adalah nilai Kriteria Ketuntasan Minimum (KKM) kelas V SDN 5 Sengkol pada mata pelajaran Pendidikan Kewarganegaraan yaitu 75 .

Berdasarkan hasil analisis ulangan harian sebelum diberikan tindakan diperoleh hasil belajar sebanyak 8 siswa atau $38,1 \%$ yang telah mencapai KKM. Dan yang belum sebanyak 13 siswa atau 61,9\% degan Nilai rata-rata kelasnya adalah 65 .

\section{Hasil Penelitian}

\section{Siklus I}

Pelaksanaan tindakan pada siklus I di laksanakan pada semester I, pada bulan Oktober 2018. pelaksanaan tindakan ini sesuai dengan program semester mata pelajaran Pendidikan Kewarganegaraan kelas $\mathrm{V}$ Semester I, standar kompetensi -Memahami Kebebasan Berorganisasi, dengan kompetensi dasar menampilkan peran serta dalam memilih organisasi di sekolah.

Pelaksanaan tindakan pada siklus II ini di lakukan dalam 4 (empat) tahapan, yaitu dengan alur perencanaan (planning), implementasi tindakan (acting), observasi dan interpretensi (observing), dan refleksi (reflekting).

Pelaksanaan kegiatan mengacu 
padaa skenario yang telah ditetapkan didalam rencana pelaksanaan pembelajaran. Yang menjadi central poin kegiatan pada siklus I ini adalah dilaksanakan observasi atau pengamatan terhadap pelaksanaan pembelajaran berlangsung, dan pemberian soal tes formatif saat pembelajaran telah selesai.

Hasil observasi di lapangan di jadikan bahan refleksi untuk perbaikan rencana pada siklus berikutnya. Pada siklus I ini, masih banyak kelemahan- kelamahan, di antaranya sebagai berikut, guru kurang keras dalam mengucapkan salam, guru kurang jelas dalam memberikan instruksi terhadap metode Card Sort. Pengelolaan waktu yang kurang optimal, karena ada siswa yang belum selesai mempresentasikan materi waktu sudah habis. Dari aktivitas belajar siswa, siswa kurang serius dalam memperhatikan guru, siswa masih malu-malu bersama kelompoknya menempel kartu dalam pembelajaran, siswa belum banyak berpartisipasi dalam diskusi kelompok.

Dari hasil belajar siswa, terjadi peningkatan kemempuan pemahaman jika dibandingkan dengan hasil pratindakan. Hal ini di lihat dari nilai tes formatif siswa. Dari 21 siswa, sebanyak 10 siswa atau 47,6\% dari siswa tuntas dalam pembelajaran, dan 11 siswa atau 52,4\% tidak tuntas dalam pembelajaran. Nilai rata-rata pada siklus I baru mencapai 71,66, jadi mencapaai ketuntasan klasikal yang di tetapkan yaitu $\geq$ 85.Secara garis besar siklus I berjalan dengan baik dan kondusif, walaupun hasil belajar siswa belum mencapai rata-rata 75. Masih banyak siswa yang belum memenuhi target KKM. Hal ini harus dijadikan suatu yang harus dibenahi dalam pelaksanaan siklus II.

\section{Siklus II}

Pelaksanaan tindakan pada siklus II di laksanakan pada semester I, pada bulan November 2018. pelaksanaan tindakan ini sesuai dengan program semester mata pelajaran Pendidikan Kewarganegaraan kelas $\mathrm{V}$ Semester I, standar kompetensi -Memahami Kebebasan Berorganisasi, dengan kompetensi dasar menampilkan peran serta dalam memilih organisasi di sekolah.

Pelaksanaan tindakan pada siklus II ini di lakukan dalam 4 (empat) tahapan, yaitu dengan alur perencanaan (planning), implementasi tindakan (acting), observasi dan interpretensi (observing), dan refleksi (reflekting).

Pelaksanaan kegiatan mengacu padaa skenario yang telah ditetapkan didalam rencana pelaksanaan pembelajaran. Yang menjadi central poin kegiatan pada siklus II ini adalah dilaksanakan observasi atau pengamatan terhadap pelaksanaan pembelajaran berlangsung, dan pemberian soal tes formatif saat pembelajaran telah selesai.

Berdasarkan hasil pengamatan yang terjadi pada siklus kedua, peneliti menemukan peningkatan yang maksimal dalam hasil belajar Pendidikan Kewarganegaraan pada siswa kela V SDN 5 Sengkol sebagai berikut: (1) Kekurangan pada siklus-siklus sebelumnya sudah mengalami perbaikan dan peningkatan sehingga menjadi lebih baik, (2) Prestasi belajar siswa pada siklus II sudah mencapai KKM 75, (3) Jumlah siswa yang memperhatikan semakin banyak karena perlengkapan metode Card Sort dan cara pembelajaran yang di lakukan oleh guru semakin baik, sehingga siswa dapat memperhatikan pelajaran secara maksimal serta hasil belajar siswa pun menjadi lebih baik.

Dari hasil belajar siswa, terlihat dari 21 siswa yang tuntas 20 siswa atau 95\% dengan nilai rata-rata 88. Pada siklus II ini, nilai siswa sudah memenuhi KKM yang telah di tentukan. Maka pada siklus II dapat di simpulkan bahwa dengan metode Card Sort dapat meningkatkan hasil belajar PKn pada siswa Kelas V SDN 5 Sengkol tahun pelajaran 2018/2019.

\section{PEMBAHASAN}

\section{Hasil Rekapitulasi}

Pendidikan $\begin{array}{cr}\text { Rekapitulasi hasil } & \text { belajar } \\ \text { Kewarganegaraan } & \text { Melalui }\end{array}$ 
strategi pembelajaran Card Sort.pada siklus I jumlah siswa yang tuntas sebaanyak 8 orang atau $38,1 \%$ sedang yang tidak tutas 13 orang atau $61,9 \%$. Pada siklus II jumlah siswa yang tuntas sebanyak 20 daari 21 siswa atau $95 \%$ sedang yang tidak tuntas 1 siswa atau $0,5 \%$

\section{Kondisi awal}

Dari hasil pengamatan kami, ternyata pembelajaran Pendidikan Kewarganegaraan SDN 5 Sengkol Tahun pelajaran 2018/2019 sebelumnya hanya menggunakan metode ceramah dan tanpa menggunakan metode pembelajaran lain. Hal ini menjadi salah satu faktor penyebab kenapa hasil belajar siswa pada mata pelajaran PKn di sekolah tersebut rendah, hasil belajarnya pun juga kurang dari Kriteria Ketuntasan Minimal (KKM) yang telah ditentukan.

\section{Kondisi akhir}

Setelah diadakanya pembelajaran

Pendidikan Kewarganegaraan dengan menggunakan metode Card Sort di SDN 5 Sengkol tahun pelajaran 2018/1019 dapat kita lihat ternyata perhatian siswa dalam mengikuti pembelajaran Pendidikan Kewarganegaraan cukup tinggi, meskipun pada awalnya (Siklus I) hanya beberapa siswa saja yang memperhatikan dan hasil belajar pada saat test formatif juga masih kurang dari KKM yang telah ditentukan, itu selain dikarenakan media dan model pembelajaran yang baru mereka kenal, juga disebabkan karena banyak siswa yang tidak fokus terhadap instruksi guru mengenai mekanisme penerapan metode Card Sort.

Dari hasil penelitian dan pembahasan maka dapat di simpulkan bahwa menggunakan metode Card Sort dapat meningkatkan hasil belajar PKn bagi siswa Kelas V SDN 5 Sengkol tahun pelajaran 2018/2019. Hal ini di tunjukkan berdasarkan hasil belajar pada siklus I yaitu hasil rata- rata hasil belajar pada kondisi awal sebesar $55,6 \%$. Siklus I ke Siklus dan pada siklus II sebesar 83,3\%. Dan hipotesis yang menyatakan bahwa -dengan menggunakan Metode Card Sort dapat meningkatkan Jurnal Pendidikan Mandala hasil belajar siswa dalam mata pelajaran PKn materi memahami kebebasan berorganisasill bagi siswa kelas V SDN 5 Sengkol tahun pelajaran 2018/2019, di terima kebenarannya. Dan dari hasil belajar siswa di atas dapat membuktikan bahwa pembelajaran ini efektif meningkatkan hasil belajar pada siswa

\section{KESIMPULAN}

Berdasarkan hasil penelitian dan pembahasan maka dapat disimpulkan bahwa dengan menggunakan metode Card Sort dapat meningkatkan hasil belajar PKn bagi siswa kelas V SDN 5 Sengkol tahun pelajaran 2018/2019. Hal ini ditunjukkan berdasarkan dari ketuntasan belajar siswa. Jumlah siswa yang mencapai nilai KKM pada siklus I sebanyak 8 siswa $(38,1 \%)$, siklus II sebanyak 13 siswa $(61,9 \%)$ Sedangkan pencapaian nilai rata-rata kelas pada pra siklus adalah 66, siklus I adalah adalah 79,72 dan pada siklus II adalah 88. Dari rata-rata tersebut berarti ada kenaikan nilai sebesar 5,66 poin dari pra siklus menuju siklus I, dan terdapat kenaikan 8,28 poin dari siklus II .

\section{Saran}

Berdasarkan kesimpulan di atas, hal-hal yang sebaiknya di lakukan oleh guru dalam pembelajaran agar siswa mencapai hasil belajar yang memuaskan adalah sebagai berikut :

1. Sebagai bahan masukan bagi guru dalam melaksanakan pembelajaran khususnya pembelajaran Pendidikan Kewarganegaraan untuk menggunakan metode Card Sort sehingga pembelajaran menjadi lebih optimal dan menyenangkan.

2. Sebelum melaksanakan pembelajaran, sebaiknya guru menyiapkan segala kebutuhan yang diperlukan baik itu metode ataupun media dengan sebaik- baiknya.

3. Kepada guru sebaiknya lebih kreatif dan variatif dalam menggunakan metode pembelajaran. Hal ini akan menghilangkan kejenuhan kepada siswa selama mengikuti proses pembelajaran.

4. Guru dalam mengajar hendaknya melibatkan siswa secara aktif agar siswa merasa lebih dihargai dan diperhatikan 
sehingga akan meningkatkan perilaku belajar yang baik.

\section{DAFTAR PUSTAKA}

Arikunto, $\quad 2008$. PenelitianTindakanKelas. Jakarta: PT Bumiaksara.

Arifin, Zainal. 1988. Evaluasi Instruksional Prinsip-Teknik-Prosedur. Bandung : Remaja Rosdakarya.

Ardianzah, Nur. Implementasi Permendiknas.2012. (Online), (http://ardianzahnur.blog spot.com/2012/08/implementasipermendiknas-no-23-tahun_1470.html/. Di akses 09 Desember 2014).

Darmono, Ikhwan Sapto. 2008.Pendidikan Kewarganegaraan untuk SD/MI Kelas V. Jakarta : Pusat Perbukuan Departemen Pendidikan Nasional.

Daryono dkk. 1998. Pengantar Pendidikan Pancasila dan Kewarganegaraan. Jakarta : PT Rineka Cipta.

Daryono dkk. 1998. Pengantar Pendidikan Pancasila dan Kewarganegaraan. Jakarta : PT Rineka Cipta.

Dimyati. 2002. Belajar dan Pembelajaran. Jakarta : PT Rineka Cipta.

Djamarah, Syaiful Bahri. 1995. Strategi Belajar Mengajar. Jakarta: PT. Rineka Cipta. Haryanto.

Pengertian hasil Belajar.2010. (Online). (http://belajarpsikologi.com/peng ertianprestasi

belajar/.Diakses06Oktober2014)Mastugin obebasanBerorganisasi.2012.(Online).(ht tp://mastugino.blogspot.com/2012/11/keb ebasan-berorganisasi.html. Di akses 11 November 2014)

Sanjaya, Wina. 2014. Strategi Pembelajaran Berorientasi Standar Proses Pendidikan. Jakarta : Kencana Penanda Media Group.

Slameto. 1991. Belajar dan Faktor-faktor yang Mempengaruhi. Jakarta : PT Rineka Cipta. Susanto, Ahmad. 2013. Teori Belajar dan Pembelajaran di Sekolah Dasar. Jakarta : PT FajarInter Pratama Mandiri.

Sutikno, Sobry. 2014. Metode dan ModelJurnal Pendidikan Mandala model Pembelajaran. Lombok : Holistica Lombok. Syah, Muhibbin. 2010. Psikologi Belajar. Jakarta : PT Raja Grafindo Persada.

Widihastuti, Setiati. 2008. Pendidikan Kewarganegaraan. Jakarta : PT Pustaka Insan Madani.

Wiriaatmadja, Rochiati. 2008. Metode Penelitian Tindakan Kelas. Bandung. PT Remaja Rosdakarya.

W.J.S. Poerwodarminta. 2006. Kamus Bahasa Indonesia Edisi Ketiga. Jakarta. Balai Pustaka.

Zaini, Hisyam. 2008. Strategi Pembelajaran Aktif. Yogyakarta. Pustaka Insan Madani. 